Ewa Pajewska

Instytut Językoznawstwa Uniwersytetu Szczecińskiego

\title{
„Twórczość obca nam klasowo" - analiza komunikacyjno-językowa doniesień agenturalnych, informacji, notatek i uwag osobowych źródel informacji (OZI) o środowisku literackim w latach 1956-1990
}

Przedmiotem podjętej poniżej analizy są teksty będące bezpośrednim efektem aktywności agenturalnej w środowisku literackim na rzecz autorytarnego, niedemokratycznego i niesamodzielnego politycznie państwa, jakim była Polska Rzeczpospolita Ludowa ${ }^{1}$. Zostały one zebrane i opublikowane przez pracowników Instytutu Pamięci Narodowej w wieloautorskiej monografii pt. ,,Twórczość obca nam klasowo". Aparat represji wobec środowiska literackiego 1956-1990 [Chojnowski, Ligarski, red. 2009]. Analizie poddano wyłącznie te teksty, które są bezpośrednią rejestracją lub opracowaniem konkretnego donosu osoby zarejestrowanej jako źródło informacji. Nie analizowano tych, których autorami byli funkcjonariusze Służby Bezpieczeństwa (SB).

Donoszenie to zjawisko 'udzielania potajemnie informacji przełożonym lub przedstawicielom władzy o czyimś prawdziwym lub rzekomym wykroczeniu lub złym postępowaniu' [Żmigrodzki, red., dostęp 2019] - typowe dla wszystkich wielkich cywilizacji i pożądane przez sprawujących władzę w każdym systemie organizacji państwa, dla których było i jest nadal użytecznym narzędziem do likwidowania zagrożeń i utrzymania dominacji ${ }^{2}$. Stało się stałym elementem rzeczywistości społecznej, kulturowej i politycznej. To spowodowało, że w języku występują rozbudowane, zróżnicowane stylistycznie łańcuchy synonimiczne zarówno w odniesieniu do tego pojęcia, np. delatorstwo,

1 Polska Rzeczpospolita Ludowa (PRL) to urzędowa nazwa państwa polskiego w latach 1952-1989. W latach 1945-1952 nosiło ono nazwę Rzeczpospolita Polska.

2 Michael Foucault pisze: „Dominacja jest ogólną strukturą władzy, której odgałęzienia i pośrednie efekty zstępują aż do najbardziej wobec niej opornych społecznych drobin" [Foucault 1998a: 191]. 
denuncjowanie, kapowanie, kablowanie, sypanie, jak i do osób, które donoszą, np. sykofant, delator, kapuś, kabel, wtyka, wtyczka, kapucha, gumowe ucho, konfident, agent, szpicel.

Denuncjacja do XX wieku powszechnie nie była wartościowana pozytywnie, chociaż stanowiła przejaw lojalności wobec władcy lub państwa. Dopiero systemy totalitarne - faszyzm oraz komunizm - podniosły ją do godności cnoty i obywatelskiego obowiązku, czyniąc z niej istotę budowanej za pomocą terroru i propagandy relacji między organami państwa a jednostką. Maciej Zakrzewski zwraca uwagę na to, że

[o]prócz uetycznienia denuncjacji państwo totalitarne czyniło z niej nie tylko pewien element stanu wyjątkowego i instrument walki z kontrrewolucją, lecz także - podobnie jak luźno sformalizowany terror - stały sposób zarządu organizacją polityczną, która nie tyle kontrolowała, ile wychowywała nowego człowieka. [Zakrzewski 2017: 15]

Denuncjacja wpisała się w dyskursywny obraz świata PRL, którego immanentnymi cechami były ograniczanie wolności jednostki i budzenie strachu. Robert Klementowski [2017: 193] przypisuje jej funkcję społeczną (narzędzia załatwiania porachunków wewnątrz grupy) oraz polityczną (pozwalającą na rozpowszechnianie przekonania o omnipotencji państwa i burzenie dotychczasowych systemów wartości).

Rządzący zdawali sobie sprawę z roli, jaką przypisywano w społeczeństwie pisarzom, którzy - mając moc sprawczą przekazywania wiedzy - mogli być zagrożeniem dla rządzących [Rokicki 2011]. O podporządkowaniu dyskursu publicznego przez realizację kategorii władzy i wiedzy była mowa w wielu pracach z zakresu filozofii [Foucault 1977, 1998a; Laclau, Mouffe 2007], socjologii [„Studia Socjologiczne” 2012] czy językoznawstwa [Kamińska-Szmaj, Piekot, Poprawa, red. 2013]. Wiedza o tym, w jaki sposób myślą literaci i jakie działania mogą podjąć, była istotna dla rządzących, którzy pragnęli mieć całkowity wpływ na kreację wizji rzeczywistości przez wszystkich w to zaangażowanych „ludzi słowa”.

$\mathrm{Z}$ obecnej perspektywy teksty agenturalne są zapisem fragmentu historii naszego społeczeństwa, a punkt widzenia dzisiejszego odbiorcy ze względu na kompetencje językowe i pozajęzykowe podlega ciągłym zmianom.

Wymaga to uwzględnienia w analizie wielu elementów aktu komunikacji, szczególnie tych, które zaproponowali Dell Hymes $[1968]^{3}$ i Waldemar

3 W skonstruowanym przez siebie modelu aktywności werbalnej Dell Hymes wyróżnił: a) ramę, tj. miejsce, czas oraz uwarunkowania psychologiczne, b) uczestników, w tym 
Czachur [2014]. Doniesienia są elementem dyskursywnego obrazu świata. Czachur, odwołując się do osiągnięć amerykańskich kognitywistów i polskich etnolingwistów badających językowy obraz świata, wprowadza kategorię DOS do polskiego językoznawstwa i zwraca uwagę na to, że

[j]eśli spojrzymy na dyskurs jako na działania językowe występujące w formie tekstów, tworzących rzeczywistość w postaci wiedzy językowej, nowych znaczeń i sensów, to analiza dyskursów opierać się powinna z jednej strony na analizie różnorakich strategii komunikacyjnych realizowanych $\mathrm{w}$ danym dyskursie przez poszczególnych aktorów dyskursu, a z drugiej strony na opisie wynegocjowanej wiedzy w formie aktualnych znaczeń. [Czachur 2014: 98]

Realizacja tak zakreślonego celu - wskazanie podstawowych mechanizmów profilowania wiedzy językowej - wymaga wyodrębnienia w badanych tekstach podstawowych pojęć, słów sztandarowych, metafor, językowych wykładników wartościowania, symboli kolektywnych oraz wzorców argumentowania.

Zabezpieczone klauzulą tajności teksty agenturalne były niedostępne dla badaczy różnych dyscyplin naukowych i dopiero od niedawna stały się przedmiotem zainteresowania historyków i językoznawców [Sauerland 2000; Dojka 2008, 2011; Musiał 2007; Klementowski 2017].

Poddany analizie zbiór zróżnicowanych formalnie 63 tekstów pochodzi z okresu 1956-1990. Ta rozpiętość czasowa powoduje, że mamy do czynienia z tekstami, które pisane były przez przedstawicieli co najmniej dwóch generacji. Skutkuje to tym, że uczestnicy dyskursu publicznego mogą mieć odmienne podejście do otaczającej rzeczywistości, wynikające z różnicy doświadczeń życiowych. Odzwierciedla się ono w konstrukcji tekstów i przyjmowanych strategiach nadawczych.

Fenomenu donosicielstwa w państwie niedemokratycznym, podporządkowanym ZSRR nie można analizować z pominięciem kontekstu historycznego i ideologicznego. Polska po drugiej wojnie światowej była krajem zniszczonym, ze zmienionymi granicami, $\mathrm{z}$ doświadczeniem wielkich przemieszczeń ludności, musiała znaleźć miejsce do funkcjonowania w nowych realiach geo-

nie tylko nadawcę i odbiorcę, ale i wszystkich obecnych podczas aktu komunikacji, bez względu na to, czy zabierają głos, czy też nie, c) cel i intencję oraz rezultat aktywności komunikacyjnej, d) zawartość przekazu (temat) i jego styl, e) tonację, f) kanały komunikacyjne i odpowiadające im kody, g) normy i zwyczaje interakcji oraz normy interpretacji, h) typy aktywności komunikacyjnej, takie jak np. instrukcja, rozkaz, informacja, doniesienie, protokół itp. 
graficznych, materialnych i politycznych. Na konieczność uwzględnienia odnoszących się do relacji między językiem a rzeczywistością społeczno-kulturową systemów kognitywnych w kontekście pragmatycznym zwracali uwagę już Hymes [1966: 1-34, 1967], John J. Gumperz [1982] czy Paul Friedrich [1972: 270-300]. Szerzej na ten temat z perspektywy socjologicznej, upominając się o szersze uwzględnienie kontekstu w językoznawstwie, pisze też Tomasz Zarycki [2012: 57-73].

Okres, z którego pochodzą teksty, podzielić można na trzy etapy, różniące się stylem rządzenia, wynikającym zarówno z politycznej sytuacji zewnętrznej, jak i z wewnątrzkrajowej koncepcji uprawiania polityki przez kolejne kierownictwa partyjne.

Pierwszy obejmuje lata 1956-1970. Jest to okres charakteryzujący się przeprowadzeniem destalinizacji i kilku reform w systemie realnego socjalizmu, co doprowadziło do pewnego uniezależnienia realizowanego politycznego modelu państwa od wzorów radzieckich. Nie spełniły się jednak nadzieje środowiska literackiego na liberalizację. Aparat bezpieczeństwa największe zagrożenie widział w kontaktach pisarzy z Radiem Wolna Europa i pismami polskimi wydawanymi za granicą, szczególnie z paryską „Kulturą”. Konrad Rokicki [2011] wskazuje na takie wydarzenia, jak: likwidacja „Po prostu”, rozgrywka przeciw Antoniemu Słonimskiemu, list 34 i kontrlist, obrona Dziadów, reperkusje wojny sześciodniowej, które stanowiły oś tematyczną zainteresowania SB. Punktem przełomowym był rok 1968, w którym doszło do antykomunistycznych wystąpień na uniwersytetach, brutalnej nagonki antysemickiej oraz interwencji zbrojnej w Czechosłowacji. Z tego okresu pochodzą 32 teksty, z czego 13 z roku 1968.

Drugi etap to lata 1970-1980. W tym okresie nastąpiła radykalna zmiana koncepcji zarządzania gospodarką, która dzięki kredytom miała stać się nowoczesna i konkurencyjna. Edward Gierek zmienił politykę wobec środowiska literackiego. Chciał nie dopuścić do konsolidacji środowiska opozycyjnego wobec pisarzy związanych z partią i dlatego dążył do wzmocnienia w tym środowisku roli partii i izolacji pisarzy ,niepokornych" wobec systemu. Z tego okresu pochodzą tylko trzy teksty.

Trzeci etap obejmuje lata 1980-1990. W 1980 roku rozpoczynają się w wielkich zakładach przemysłowych strajki robotników inicjowane i kierowane przez NSZZ „Solidarność”. Rząd Wojciecha Jaruzelskiego w odpowiedzi na nie wprowadził stan wojenny w grudniu 1981 roku. Represje dotykają wtedy także środowisko pisarzy. Wielu z nich zostaje internowanych. W sierpniu 1893 roku zostaje rozwiązany Związek Literatów Polskich i Pen Club. To doprowadziło do rozbicia środowiska, a w konsekwencji do powstania dwóch związ- 
ków: Stowarzyszenia Pisarzy Polskich i neo-Związku Literatów Polskich ${ }^{4}$. $\mathrm{Z}$ tego okresu w pracy umieszczono 28 materiałów agenturalnych.

Ważne jest to, że szczególnym zainteresowaniem SB cieszyły się zachowania warszawskich literatów, co potwierdza znaczenie stolicy jako głównego ośrodka wpływu. Z Warszawy pochodzą 53 teksty ( 22 powstały w pierwszym okresie, $2 \mathrm{w}$ drugim, a $29 \mathrm{w}$ trzecim). Siedem zarejestrowano we Wrocławiu (wszystkie w latach 60.) i po jednym w Krakowie (z 1968), Szczecinie (z 1975) i Rzeszowie (z 1983).

Ich nadawcy kierują się różnymi pobudkami - od najniższych, jakimi są chęć zemsty, wzbogacenia się czy zazdrość, po działania wynikające z utrwalonych przekonań ideologicznych.

Uczestnikami w tym akcie komunikacji są: a) podmiot czynny (tzw. OZI, czyli osobowe źródło informacji ${ }^{5}$ ), b) podmiot bierny (osoba lub osoby, o których traktuje donos ${ }^{6}$, w tym wypadku ludzie ze środowiska literatów), c) podmiot pośredniczący w przyjmowaniu, sporządzaniu, opracowywaniu i przekazywaniu informacji (najczęściej oficer operacyjny SB, który porządkuje, ocenia, ewidencjonuje i przekazuje informację do wyższych stopniem czy kompetencjami służbowymi urzędników aparatu bezpieczeństwa), d) odbiorca lub odbiorcy (osoby podejmujące decyzje operacyjne i polityczne).

Różne były sposoby werbowania donosicieli. Część z tych osób sama deklarowała chęć współpracy ze Służbą Bezpieczeństwa, część została zmuszona do takiej działalności. Byli nimi przede wszystkim dziennikarze, pisarze i adwokaci ${ }^{7}$. Aktywnym źródłem informacji mogły być także osoby związane ze środowiskiem, jak np. żona Pawła Jasienicy - TW „Ewa”.

Analiza objęła nie tylko teksty pisane samodzielnie przez donosicieli (20). Uwzględnione zostały w niej także takie, które zostały opracowane lub spisane na podstawie rozmów i relacji przez oficerów prowadzących Służby Bezpieczeństwa (43). Kategorie osobowych źródeł informacji Urzędu Bezpieczeństwa (UB) i Służby Bezpieczeństwa od 1955 do 1990 roku ulegały zmianom [Musiał

4 Po rozwiązaniu ZLP władze przystąpiły od razu do tworzenia nowego związku pod tą samą nazwą, mając wpływ na obsadę stanowisk i skład osobowy.

5 W IV Wydziale Departamentu III analizowano twórczość pisarzy, którzy uznawani byli za potencjalne zagrożenie dla ustroju. Analizy te sporządzali konsultanci, którzy recenzowali teksty, oceniali, w jakim stopniu treść odpowiada ideologicznym wytycznym partii, a także ustalali tożsamość pisarzy piszących pod pseudonimem [Bereś 2010: 23-39].

6 Tzw. figurant, czyli 'osoba, na której temat Służba Bezpieczeństwa zdobywała i gromadziła informacje’ [Żmigrodzki, red., dostęp 2019].

7 W 1969 roku tajnymi współpracownikami było w kraju 10 literatów i 70 dziennikarzy [Ligarski 2009: 23]. 
2005: 17-18]. Badane teksty tworzone były przez tajnych współpracowników (TW), kontakty operacyjne (KO), kontakty poufne (KP) oraz konsultantów $(\mathrm{K})^{8}$. Jedna osoba mogła w czasie swojej działalności agenturalnej być określana jako KO, TW lub też jako K. Przykładowo był tak kategoryzowany w zależności od etapu współpracy Kazimierz Koźniewski. Często posługiwano się kilkoma pseudonimami na identyfikację jednego źródła informacji. Kazimierz Koźniewski oznaczany był: „K”, „KK” i „33”, Jan Maria Gisges: „Maria”, „JMG” i „Marian”, Zofia O’Bretenny: „Ewa” i „Max”.

Teksty były pisane maszynowo bądź ręcznie. Przy każdym znajduje się miejsce, data, informacja o treści oraz nazwisko osoby przyjmującej, sporządzającej bądź opracowującej materiał" . W nagłówkach większości z nich podana jest informacja, czego dotyczą, np. „dotyczy zamierzeń członków byłego Klubu Krzywego Koła” [s. 134] ${ }^{10}$, „na temat przebiegu i wyników wyborów w oddziale warszawskim ZLP” [s. 219], „,doniesienie [...] dotyczące listu protestacyjnego Pawła Jasienicy do rektora Uniwersytetu Warszawskiego przeciwko karaniu studentów uczestniczących w proteście po zakazie wystawiania Dziadów" [s. 275]. Jest to typowy element wzorca gatunkowego pisma urzędowego. Pamiętać należy, że każdy taki tekst był wprowadzany w ściśle zdefiniowany obieg dokumentów, a następnie archiwizowany. Teksty nazwane doniesieniami pochodziły od tajnych współpracowników (13), od konsultanta (2) oraz osoby oznaczonej jako źródło (1). TW „Ewa”"11 dostarczył siedem doniesień w formie maszynopisu, które były przyjęte przez oficerów prowadzących, TW „Konar”12 - trzy, TW Adam ${ }^{13}$, TW „Stanisław Wisłocki” oraz TW „Lachowicz” po jednym. Dwa doniesienia pochodziły od konsultanta o pseudonimie „K” oraz jedno od informatora o nieustalonym statusie („Promień”). Inne teksty to notatki. Dziewięć z nich to notatki służbowe. Cztery sporządzone zostały po spotkaniu z TW „Konarem”, cztery z kontaktem poufnym „Grzesiem”14 oraz jedna ze spotkania z kontaktem operacyjnym „Luckym”15. Mamy

8 Stosowanie skrótów nazw używanych w świecie służb agenturalnych jest powszechne.

9 Autorzy wyboru tekstów dokonali korekty błędów ortograficznych i interpunkcyjnych. Analiza w związku z tym nie może uwzględnić tego typu kompetencji nadawcy przekazu.

10 Wszystkie cytaty pochodzą z publikacji Chojnowski, Figarski, red. 2009, w nawiasie podaję numery stron. W cytatach pojawiają nawiasy kwadratowe, które wprowadzili redaktorzy tej pracy.

11 Zofia O’Bretenny, żona Pawła Jasienicy.

12 Henryk Worcell (właśc. Tadeusz Kurtyka), zwerbowany w połowie 1964 roku, pisarz i publicysta.

13 Roman Waschko, dziennikarz muzyczny, popularyzator jazzu w Polsce.

14 Henryk Gaworski.

15 Władysław Pociej, adwokat, obrońca Melchiora Wańkowicza. 
też wśród badanych tekstów trzy notatki informacyjne, dwie notatki ze spotkania, dwie notatki ze źródła. Odrębną grupę stanowią informacje: informacje operacyjne konsultanta (13), informacje kontaktu operacyjnego $(5)^{16}$ oraz pięć tekstów o charakterze informacyjnym, dla których trudne jest ustalenie przynależności do konkretnej grupy. Należy zwrócić uwagę na fakt, że teksty sporządzane przez oficerów prowadzących mają w nagłówku informacyjnym szczegółową charakterystykę sposobu pozyskania. Tu 15 ma adnotację, że zostały opracowane przez oficerów prowadzących, 12 oznaczono jako sporządzone przez oficerów prowadzących, a cztery jako spisane. Ponadto jeden opisany jest jako ocena dokonana przez konsultanta oraz jeden jako uwagi konsultanta przekazane oficerowi ${ }^{17}$. Taki opis każdego doniesienia, notatki czy informacji świadczy o tym, że były one wykorzystywane w działaniach operacyjnych funkcjonariuszy policji politycznej, a także dygnitarzy partyjnych, którzy ostatecznie podejmowali decyzje o dalszym postępowaniu wobec konkretnych osób. Można mówić o zbiorowym odbiorcy, uporządkowanym według hierarchii sprawowania władzy. Taki system dokumentacji świadczy także o tym, że przewidziano, iż może ona służyć przez wiele lat i być wielokrotnie wykorzystywana.

Na podstawowy problem w klasyfikowaniu tych tekstów zwróciła uwagę Iwona Dojka [2008]. W powyżej przedstawionej analizie liczbowej używano przede wszystkim pojęcia zbiorczego tekst agenturalny. Wszystkie z nich można określić jako donosy. Dojka [2008: 45-49] dokonała ważnego rozróżnienia dwóch terminów - donos i doniesienie. Donos według niej był tekstem, który bądź konfident pisał sam i przekazywał funkcjonariuszowi, bądź spisywany był na podstawie rozmowy przez funkcjonariusza. Sam donos nie był nigdy samodzielnym dokumentem. Przyjmujący go funkcjonariusz postępował dalej według ściśle określonych procedur i w rezultacie tworzył doniesienie. Doniesienie było już tekstem złożonym. Donos był głównym jego elementem, który - jeżeli był pisany przez konfidenta ręcznie - zostawał przepisany przez funkcjonariusza i uzupełniony o inne składniki, takie jak: nagłówek, nazwa gatunkowa, uzupełnienie informacji zawartych $\mathrm{w}$ donosie na podstawie rozmowy ze współpracownikiem, spis wydanych donosicielowi poleceń poprzedzonych tytułem zadania, zaplanowane przez funkcjonariusza dalsze działania, opatrzone nagłówkiem przedsięwzięcia lub wnioski, informacja o wiarygodno-

16 Ten status miał Jan Maria Gisges, który występował pod pseudonimami „Maria” oraz „Marian”.

17 Taki różnorodny status nadawano tekstom konsultanta „Olcha” - mamy tu dwie notatki, cztery informacje operacyjne oraz po jednej uwadze, relacji i ocenie. 
ści, uwagi o opisanych przez donosiciela zdarzeniach, niewynikające z treści donosu, lub o zachowaniu się agenta w czasie spotkania [Dojka 2008: 46].

Robert Klementowski natomiast zwraca uwagę na to, że donos ze względu na sposób powstania może mieć charakter normatywny czy nawet skodyfikowany, uzualny, opierający się na zbiorze prawideł wprawdzie niepisanych, ale przestrzeganych w praktyce komunikacyjnej, oraz mieszany, gdzie „część reguł ma charakter zwerbalizowany, inne funkcjonują tylko jako składniki świadomości nadawców profesjonalistów" [Klementowski 2017: 198].

Badacz [Klementowski 2017: 208] zrekonstruował podstawową strukturę donosu w PRL do Służby Bezpieczeństwa, na którą składa się: a) inicjalna rama tekstowa (złożona z elementów faktograficznych, miejscowości, daty, pseudonimu, nazwiska przyjmującego donos oraz miejsca przyjęcia donosu), b) treść donosu (tu: przedmiot donosu, obiekt donosu, wydarzenie dotyczące donosu, okoliczności zdarzenia), c) finalna rama tekstowa w postaci podpisu nadawcy (pseudonimu) oraz komentarza.

Wszystkie wybrane z monografii teksty, choć różne w formie, można określić mianem donosu. Jak wykazano, w badanych powyżej tekstach stosowano w nomenklaturze SB określenie doniesienie, które miało inny zakres znaczeniowy i zawsze oznaczało informację przekazaną przez tajnego współpracownika.

Celem działania konfidenta jest przekazanie informacji na temat inwigilowanych osób, mających dopomóc policji politycznej w skutecznych działaniach wobec przeciwników politycznych bądź osób lub grup oddziałujących na społeczeństwo, środowiska naukowe, studentów w inny od zamierzonego przez władzę sposób oraz utrudnienie kontaktów z ośrodkami zagranicznymi.

Podawane są nazwiska, daty, miejsca, cytowane wypowiedzi: „Zebranie ZLP w dn. 31 stycznia miało przebieg w zasadzie spokojny, ale to nie znaczy, że bez politycznych akcentów” [s. 245], „W niedzielę (2 stycznia 1966 r.) są umówieni wszyscy u Leszka K[ołakowskiego] na obiedzie, gdzie sądzę dopiero powstaną plany ewent[ualnych] posunięć przed wybraniem” [s. 240], „W toku jednej z rozmów z KP A[rnold] Słucki, mówiąc z zacietrzewieniem na temat oświadczenia Prezydium Towarzystwa Społeczno-Kulturalnego Żydów w Polsce w sprawie wydarzeń na Bliski Wschodzie stwierdził m.in.: «Oczywiście, że musimy pójść na pewne koncesje, ale nigdy nie zaakceptujemy faktu pomocy Arabom udzielanej przez rząd PRL»” [s. 262], „W dniu 28 lutego 1968 r. były $\mathrm{w}$ domu u Jasienicy, poprzednio zamówione telefonicznie, dwie studentki z UW. Jedna Żydówka (nazwisko nieznane), druga ta, co wręczała Jasienicy z [Adamem] Michnikiem podpisy, czyli Irena Grudzińska” [s. 273], „Kurczab oświadczył, że [...] czuł się właśnie tak, jakby mu wrzucono do mieszkania 
puszkę cyklonu...” [s. 284], „Osobą, która prawie pół miasta objeździła, ostrzegając i prosząc o usunięcie podejrzanych wydawnictw, była Neli Strugowa" [s. 201].

Oprócz konkretnych informacji teksty zawierały oceny postępowania i zachowania inwigilowanych osób lub też ocenę postępowania służb, np.: „Bardzo nieprzychylnie komentuje się postępowanie cenzury, która konfiskuje w «Świecie» każdy artykuł czy felieton Stanisława Brodzkiego, choć przecież wypuszczono go na wolność, nie ma żadnych oskarżeń, jest zastępca red. naczelnego i podpisuje numer. Wygląda to na zwykłą szykanę” [s. 132], „Stanowisko A[ntoniego] Słonimskiego jest absolutnie, nieprzejednanie krytyczne w stosunku do ostatnich posunięć władz. Podkreśla uporczywie..." [s. 199], „Paweł Herz [...] jego opinie są zawsze połączeniem butnych wypowiedzi Słonimskiego z asekuranckim stanowiskiem Sandauera i własnym komentarzem człowieka ciągle rozżalonego na los i ludzi” [s. 200], „Do dziś wielu z nich jest pełnych rys i kompleksów, co widać i w dalszej twórczości i w życiu osobistym" [s. 226], ,nie miesza się specjalnie ostatnio w środowisko literackie, obserwuje, pisze, pije" [s. 228], ,jedyna grupa coś «rozrabiająca» politycznie to «starcy», którzy za granicę nie bardzo mają siłę i cel pojechać, w których wieku łatwiej rozrabiać na niwie rodzimych kawiarni, niż wędrować po szlakach Afryki czy polować w Azji, jak R[oman] Bratny” [s. 229], „W sumie: spotkanie spokojne, jałowe, ale to nie znaczy, iż politycznie wygrane” [s. 246], „Panuje szalone przygnębienie” [s. 249], „przemówienia były namiętne, rozpaczliwe” [s. 252].

Mimo iż głównym celem tekstów agenturalnych jest przekazanie informacji, artykułowane są także wprost emocje w odniesieniu do osób, instytucji, redakcji, które są przedmiotem donosu: „W rozmowie wyrażał esesmańskie poglądy” [s. 208], „bojowy poeta «wczesnego» socjalizmu” [s. 227], „grupa coś «rozrabiająca» politycznie” [s. 229], ,został jako symboliczny obelisk upadłego sprzymierzenia” [s. 230], „Jeżeli idzie o Wrocław - dodatkowe niezadowolenie z pisma «Odra», które zostało według Kotowicza oddane w pacht opozycji” [s. 529], „teraz jeszcze jest czas «katzenjammeru» oraz frustracji czy - przeciwnie - euforii podszytej zaniepokojeniem” [s. 534], „teraz zależały jedynie od decyzji korowców (tak w skrócie), a ta w listopadzie była o wiele bardziej awanturnicza” [s. 537], „Mówił Wańkowicz o swojej sprawie [...] jakby była pępkiem świata" [s. 246], „główny referent zjazdu [...] zrobił drakę pijacką” [s. 250], „wielu pisarzy, zwłaszcza warszawskich, to megalomani doznający zawrotu głowy, uważają się za niezastąpione wielkości, a ich żony są zdania, że ich mężowie są równi Gomułce i Ochabowi” [s. 260], „«[...] ma [...] opinię» wrednej baby, rozrabiary, która chce zrobić karierę na uwięzieniu swojego syna” [s. 236], „uważa za bezczelnego grafomana” [s. 240]. 
Często w odniesieniu do inwigilowanych osób używane są takie nacechowane emocjonalnie przymiotniki, jak np.: bezczelny, tatwowierny, zarozumialy, roztrzepany, rozżalony, szowinistyczny, wredny, zażarty. Używanie takich określeń atrybutywnych ma charakteryzować osoby, o których jest mowa w doniesieniach agenturalnych. Przede wszystkim uwypuklane są negatywne cechy osobowościowe. Przymiotnikami nadużywanymi w badanych tekstach są partyjny i bezpartyjny.

Liczną grupę stanowią czasowniki odnoszące się do sposobu mówienia, co jest oczywiste $z$ tego powodu, że przedmiotem donosu były głównie wypowiedzi, rzadziej czyny inwigilowanych osób. Do tej grupy można zaliczyć takie czasowniki, jak np.: jąkać się, mówić, odszczekiwać się, odcinać się, opluwać, popierać, przerzucać się, rozdrapywać, stwierdzać, tlumaczyć, zaręczyć. Stosunkowo często powtarzają się także czasowniki: dowiadywać się, interweniować, gotować się, knuć, miotać się, obiecać, odbywać, podskakiwać, pozwolić, przekazywać, rozrabiać, podskakiwać, trzymać się, zmieszczanieć.

O tematyce donosu wiele mówią też używane w tekstach rzeczowniki, takie jak: agitacja, artysta, awantura, cenzura, chaos, cierpiętnik, drobny urzędnik, dygnitarz, egzekutywa, ekstrema, kawiarnia, koteria, krytyka, literat, literatura, pisarz, poeta, posiedzenie, pozycja, proces, prowokacja, publicystyka, redakcja, redaktor, rewizja, rzeczywistość, stanowisko, stronnictwo, wartość, wydawnictwo, wywrotowiec, zarozumialec, zebranie, żer. Tematami przewodnimi są literatura, powiązania towarzyskie i ideologiczne, stosunek do partii, poprawność bądź niepoprawność polityczna.

Donosiciele nie tylko informują o wypowiedziach i zachowaniach zagrażających interesom partii, ale także podkreślają wypowiedzi, które aprobują linię polityczną rządzących. Przykładem może być taki fragment: „W redakcji «Życia Literackiego» prof. Grzybowski powiedział wobec zespołu, że ostatnie wypadki unicestwiają na całe lata pracę partyjno-ideową wśród młodzieży i niszczą zamierzenie Waldecka Rocheta, który właśnie w oparciu o przykład Polski skupiał dookoła FPL lewicę francuską" [s. 285].

Osobowe źródła informacji kierowały się różnymi motywacjami. Jeżeli chodzi o chęć osiągnięcia korzyści finansowych, to nigdy taki powód nie był wyrażony bezpośrednio.

Z kontekstu natomiast można wywnioskować, że jedną z motywacji była zazdrość lub chęć zemsty, co wyrażone jest wprost w tekstach, np.: „Mówiła mi to w kawiarni «Antycznej» wczoraj mama Tyszkiewiczowa, która od lat znam ze «Szpilek», a która dostała na gwiazdkę od Beatki auto” [s. 242], ,Wańkowicz uchodził w świecie literackim za wielkiego dygnitarza, gdyż pozwalał sobie na więcej [...], np. za wieczorki autorskie kazał sobie płacić po 2 tys. zł, czego nie 
dostawał nigdy żaden z innych pisarzy” [s. 197], „Bratny [...] przeszedł na duże pieniądze (przeróbka na teatr). Ostatnio przeszedł na duże zainteresowanie się scenariuszem filmowym i z tego, co zapowiada towarzysko (powtarzał mi Lew Kaltenbergh), ma zamiar przez najbliższe lata zając się filmem, bo to są pieniądze i więcej sławy” [s. 227], „Są jednostki niezadowolone lub starcy «podskakujący», ale krytykując, nic nowego nie ofiarują...” [s. 230], „trzeba pamiętać [...]. Cały «wdzięk» Tyrmanda i jego popularność wypływa raczej z jego zdecydowanie negatywnego stanowiska do dzisiejszej rzeczywistości, które ... potrafi ... uzasadnić w bardzo efektowny, a właściwie efekciarski sposób” [s. 123], „tak zwana «opozycja» ... ma na wszystko: kartki, pomoc lekarską, domy pracy... Wyczuwa się tendencje, że należałoby ich pozbawić tej opieki ZLP" [s. 529].

Osoby współpracujące z SB starają się udzielać rad, krytykować poczynania służb i władz partyjnych, mając domniemanie o współuczestnictwie w działaniach władz. Jest to wyraźnie wyartykułowane w podanych poniżej przykładach.

Ale nawet na istniejących jeszcze płaszczyznach styku towarzyskiego (stołówka) w ostatnim czasie daje się zauważać coraz ściślejsze zamknięcie się we własnym gronie, zwłaszcza ludzi prowadzących do niedawna szeroko zakrojoną ,agitację towarzyską" (Tomasz Burek) [...] Ocknęła się organizacja partyjna, a mówiąc ściślej, jej I sekretarz. [...] Wydaje się, iż rzeczą celową byłoby podjęcie przygotowań do jak najrychlejszego ponownego uruchomienia specjalistycznej, dobrze sprofilowanej prasy literackiej (przede wszystkim miesięczników). 21.12.1981, K „Olcha”. [s. 568-569]

Weryfikację w ZLP należy przeprowadzić [...]. Pisarze autentyczni, prawdziwi, którzy są politycznie biorąc, po stronie partii i rządu, tych trzeba zostawić w ZLP i w spokoju. [...] Pisarze zerowi o nieujawnionym, niejasnym, być może niechętnym stanowisku politycznym. Tych należy zewidencjonować ściśle i wobec każdego należy oddzielnie rozpatrzyć sposoby pozbycia się ich. Sposoby takie jak: tłumacz do tłumaczy, inny - składki, jeszcze inny - coś innego. Wreszcie grupa ostatnia: pisarze zerowi, o wyraźnym przeciw partii i rządowi obliczu i działaniu politycznym (n. W[Bartoszewski], Krzysztof Wolicki nawet - tu już można dyskutować - Jan Józef Lipski) - ich jest pewna ilość. 14.01.1982, K „33”. [s. 570]

Donos jest szczególnym typem gatunku w dyskursie władzy. Jak trudno wyznaczyć granice między donosem, doniesieniem, doniesieniem agenturalnym, sprawozdaniem, informacją czy też innym tekstem agenturalnym, 
pisali już Dojka [2008] i Klementowski [2017: 205-206]. Donosy najściślej i najboleśniej związane są z życiem społeczeństwa i, jak pokazuje historia, mimo niszczenia dokumentów z czasów PRL nadal stanowią obszerny zbiór. Zamknięte w archiwach donosy są trudno dostępne dla językoznawców. Zbiory archiwalne tego typu ujawniane są okresowo, nieraz w dużych odstępach czasu, $z$ reguły po przemianach politycznych. Fakt ten - wraz z często wciąż żywymi skutkami wykorzystywania takich dokumentów - znacząco utrudnia prace nad ich bliższym zbadaniem. Donosy osób związanych ze środowiskiem literackim, zgodnie z oczekiwaniami, pisane są sprawnym, bogatym i zróżnicowanym językiem. Ich autorzy charakteryzują się doskonałym obyciem językowym. Ludzie ci jednocześnie stanowią przykład bardzo nieetycznych postaw życiowych, będących często całkowitym zaprzeczeniem oficjalnie głoszonych przekonań. Pozytywna ocena twórczości pisarza nie może w takiej sytuacji iść w parze z osądem moralnym jego postawy i zachowania.

\section{Bibliografia}

Bereś Stanisław (2010), Stużba Bezpieczeństwa jako krytyk literacki, w: Artyści władzy, władza artystom, red. Andrzej Chojnowski, Sebastian Ligarski, Instytut Pamięci Narodowej, Warszawa, s. 23-49.

Dojka Iwona (2008), Donos i doniesienie jako gatunki tekstu, „Annales Academie Paedagodicae Cracoviensis. Studia Linquistica", t. 3, s. 44-53.

Dojka Iwona (2011), Zakłamany słownik, czyli żargon funkcjonariuszy bezpieczeństwa $P R L$, Dom Wydawniczy Rafael, IPN, Kraków.

Chojnowski Andrzej, Ligarski Sebastian, red. (2009), „Twórczość obca nam klasowo”. Aparat represji wobec środowiska literackiego 1956-1990, Instytut Pamięci Narodowej - Komisja Ścigania Zbrodni Przeciwko Narodowi Polskiemu, Warszawa.

Czachur Waldemar (2014), Dyskursywny obraz świata. Kilka refleksji, „Tekst i Dyskurs", t. 4, s. 79-99.

Foucault Michael (1977), Archeologia wiedzy, przeł. Andrzej Siemek, PIW, Warszawa.

Foucault Michael (1998a), Podmiot $i$ władza, przeł. Jacek Zychowicz, „Lewą Nogą”, nr 9, s. 174-192.

Foucault Michael (1998b), Trzeba bronić spoleczeństwa, przeł. Małgorzata Kowalska, Wydawnictwo KR, Warszawa.

Friedrich Paul (1972), Social Context and Semantic Feature: The Russian Pronominal Usage, w: Directions in Sociolinguistics: The Ethnography of Communication, red. John Gumperz, Dell Hymes, Wiley-Blackwell, New York, s. 270-300.

Gumperz John (1982), Discourse strategies, Cambridge University Press, Cambridge. 
Hymes Dell (1964), Introduction: Toward Ethnographies of Communication, „American Anthropologist", t. 66 (6), cz. 2, s. 1-34.

Hymes Dell (1967), Models of the interaction of language and social life, ,Journal of Social Issues", t. 23 (2).

Hymes Dell H. (1972), On Communicative Competence, w: Sociolinguistics. Selected Readings, red. John B. Pride, Janet Holmes, Penguin, Harmondsworth, s. 269-293.

Kamińska-Szmaj Irena, Piekot Tomasz, Poprawa Marcin, red. (2013), Język władzy, Wydawnictwo UWr, Wrocław (Oblicza Komunikacji 6).

Klementowski Robert (2017), Donos agenturalny jako gatunek, w: Antropologia donosu, red. Jarosław Syrnyk, Robert Klementowski, Oddział Instytutu Pamięci Narodowej - Komisji Ścigania Zbrodni przeciw Narodowi Polskiemu we Wrocławiu, Wrocław, s. 189-212.

Laclau Ernesto (2009), Demokracja i kwestia władzy, w: Język, dyskurs, społeczeństwo. Zwrot lingwistyczny w filozofii społecznej, red. Lotar Rasiński, Wydawnictwo Naukowe PWN, Warszawa.

Laclau Ernesto, Mouffe Chantal (2007), Hegemonia i socjalistyczna strategia. Przyczynek do projektu radykalnej polityki demokratycznej, przeł. Sławomir Królak, Wydawnictwo Naukowe Dolnośląskiej Szkoły Wyższej Edukacji TWP we Wrocławiu, Wrocław.

Musiał Filip (2019), Podręcznik bezpieki. Teoria pracy operacyjnej Stużby Bezpieczeństwa w świetle wydawnictw resortowych Ministerstwa Spraw Wewnętrznych PRL (1970-1989), wyd. 3, Instytut Pamięci Narodowej, Kraków.

„Studia Socjologiczne” (2012), nr 1: Kontekst społeczny i władza w socjologicznej analizie dyskursu, red. Dorota Rancew-Sikora, Piotr Pawliszak.

Rokicki Konrad (2011), Literaci. Relacje między literatami a władzami PRL w latach 1956-1970, Instytut Pamięci Narodowej, Warszawa.

Syrnyk Jarosław, Klementowski Robert, red. (2017), Antropologia donosu, Oddział Instytutu Pamięci Narodowej - Komisji Ścigania Zbrodni przeciwko Narodowi Polskiemu we Wrocławiu, Wrocław.

Zakrzewski Maciej (2017), Totalitarna władza i nowa jednostka. Instrumentarium Ernsta Jurgena, w: Antropologia donosu, red. Jarosław Syrnyk, Robert Klementowski, Oddział Instytutu Pamięci Narodowej - Komisji Ścigania Zbrodni przeciw Narodowi Polskiemu we Wrocławiu, Wrocław, s. 13-22.

Zarycki Tomasz (2012), Poszerzając kontekst: ku krytycznej socjologii językoznawstwa, „Studia Socjologiczne”, nr 1, s. 57-73.

Żmigrodzki Piotr, red., Wielki słownik języka polskiego, https://www.wsjp.pl [dostęp: 13 października 2019]. 
Ewa Pajewska

"Creativity Foreign to our Class" - Communication and Language Analysis of Agent Delations, Information, Notes and Personal Sources of Information (OZI - Osobowe Źródlo Informacji) about the Literary Environment in the Years 1956-1990

The purpose of the article is to present a communication and language analysis of agent texts on the Polish literary environment prepared by personal sources of information in the years 1956-1990. Their selection was made by employees of the Institute of National Remembrance from the Warsaw branch of the Commission for the Prosecution of Crimes against the Polish Nation in a monograph entitled „, Twórczość obca nam klasowo". Aparat represji wobec środowiska literackiego 1956-1990 [ "Creativity foreign to our class." Apparatus of repression against the literary environment from 1956 to 1990]. The analysis applies only to materials that are a direct record or development of a specific denunciation filed by a person registered as a source of information, but does not apply to reports, analysis of situations, statements and other texts authored by the officers of the Security Service. These are sixty-three formally diverse texts consisting of reports, information, notes and remarks from secret collaborators (TW - Tajny Współpracownik), operational contacts (KO - Kontakt Operacyjny), confidential contacts ( $\mathrm{KP}-$ Kontakt Poufny) and consultants (K - Konsultant). Primarily, the analysis takes into account all description elements of the act of communication and makes an introduction into discourse analysis of secret agent materials originating from the three stages of the Polish People's Republic. Denunciation resulting in those texts fulfils a social function as a tool for political fight against the opposition and a political function as well, allowing for spreading the belief in the omnipotence of the state and destroying the existing systems of values. The texts are mainly informative, although they are not devoid of emotion expressed linguistically in a variety of ways. The authors are aware of the value of the knowledge conveyed in the texts and of the consequences of denunciation for the people they concerned.

KEYWORDS: delation; report; personal source of information.

dr hab. Ewa Pajewska, prof. USz - Instytut Językoznawstwa, Uniwersytet Szczeciński; zainteresowania badawcze: leksykologia, komunikacja społeczna, języki specjalistyczne, język prasy, językoznawstwo kulturowe, socjolingwistyka, historia języka, ostatnio: problematyka współczesnego dyskursu medialnego, teorii komunikacji, języka polityki, mowy nienawiści oraz językowych sposobów przedstawiania starości w języku polskim. 